\title{
THE ESSENTIALS OF A CHILD LABOR LAW FOR THE DISTRICT OF COLUMBIA ${ }^{1}$
}

\author{
By Henry J. Harris, Ph.D.,
}

United States Bureau of Labor, and Secretary of District of Columbia Citizens' Child Labor Committee.

Before discussing the essential provisions of a law regulating the employment of children in the District of Columbia, it should be stated that the local Child Labor Committee is in hearty sympathy with the efforts of the Civic Center, the Public Education Association, and the numerous citizens' associations to secure a compulsory education law for the District. The necessity for such a law is so patent that it would be a waste of time to discuss the subject before this audience. The relation of a compulsory education law to a child labor law is a vital one, for perhaps the principal reason for prohibiting the labor of young children is to assure them an opportunity of obtaining the educational and other advantages offered by the public school system.

The bill proposed for the District of Columbia was drawn up on lines suggested by the National Child Labor Committee, and was carefully adapted to the needs of the District by the president of the Board of District Commissioners and the local Child Labor Committee. In its present form the bill may be called a conservative one; it contains no provisions which have not been in actual operation in other States and which experience has shown to be effective in removing the evils which also accompany the employment of children in this city.

The first part of the bill provides that no child under fourteen years of age may be employed in any occupation while the public schools are in session. During the time that the schools are not in session no child under fourteen may be employed in any factory,

1 Address at the third session of the Second Annual Meeting of the National Child Labor Committee, Washington, D. C., December 9, 1905.

(364) 
workshop, mercantile establishment, store, business office, telegraph office, restaurant, hotel, apartment house, theater, bowling alley, or in the distribution or transmission of merchandise or messages.

For children fourteen years of age, but under sixteen, the proposed law requires that such children must obtain an age and schooling certificate before securing employment. This certificate shows the age of the child, and states that the child can read and write simple sentences in the English language; it also states that the child has attended school for at least one hundred and thirty days during the school year previous to the fourteenth birthday, or during the year previous to applying for such school record, and during this time has received instruction in reading, spelling, writing, English grammar, geography, and is familiar with the fundamental operations of arithmetic, including fractions. The schooling certificates are to be approved by the superintendent of public schools, or a deputy acting under his instructions. The superintendent also keeps a duplicate of each certificate on file in his office. In addition to the age and educational qualifications, the child must also be in good health and physically able to do the work at which he expects to be employed.

The statements of the parents regarding the age of the child must be substantiated by documentary evidence, such as transcripts of birth or other certificates, unless the official in charge is convinced that it is impossible to secure such documentary evidence, in which case the affidavit of the parent or guardian will be accepted.

The employer is required to keep on file all age and schooling certificates of the children under sixteen employed by him, and to return to the children their certificates when they leave his employ. The employer must keep two complete lists of the names of such children-one on file and one posted where it can be consulted readily by the inspectors authorized by the act. In addition, in each room where children under sixteen are employed there must be posted a notice stating the number of hours of labor required on each day, specifying the hours of commencing and stopping work, and stating when the mealtimes begin and end. Any child found working at other than the times specified in this notice is to be considered as employed in violation of the law.

No child under sixteen years of age may be employed more $(365)$ 
than eight hours per day, or forty-eight hours per week, or between seven in the evening and six in the morning.

The penalties for violations of the law are the same as those imposed in most of the child labor laws of other States. In some cases, penalties may be imposed on the parents as well as on the employers. To secure the proper enforcement of the law, two inspectors are provided.

How would such a law remove the evils which now exist as the result of the employment of children? First of all, it would prevent the employment of very young children in occupations which must be classed as harmful because of their physical, mental, and moral effects on the development of the child. Thus, during the time that the public schools are not in session, children under fourteen may not be employed in factories, where the physical strain is apt to be severe, or in stores, or in the messenger service, where the influences of street life are morally dangerous. The employment of very young children in the street trades is perhaps the greatest of the child labor evils existing in the city at the present time; this and the uncalled for working of children at night will be prevented by the bill under discussion.

The regulation of children's work should not stop when the child has completed his thirteenth year; such a child is by no means ready for the exploitation of his laboring capacity to the full extent which present industrial methods make possible. The bill, therefore, not only limits the working time of children under sixteen years of age to eight hours per day, but provides that these hours shall come between $6 \mathrm{a}$. $\mathrm{m}$. and $7 \mathrm{p}$. m. and shall not amount to more than forty-eight hours per week. How successful the committee will be in securing these provisions regarding hours of labor remains to be seen, but an earnest effort will be made to persuade Congress to grant them. Some of the workmen in this city are now preparing for a struggle to secure for themselves an eight-hour day, and it must in reason be conceded that a child should not be subjected to harsher treatment than a full-grown man. From the current discussion of conditions in this city it has been demonstrated beyond question that such a provision is urgently needed. The factories in this city are those engaged in "light" manufactures, and it may be regarded as a certainty that we shall always have a number of 
such establishments because of the opportunity afforded to exploit the cheap labor of the women and children of the men engaged in the various skilled and unskilled trades of this locality. Factories engaged in this line of production always find it more profitable to use the labor of women and children-especially of children-than to instal machinery, and as this type of industry is particularly subject to periods of intense activity, we find the factory children of the District worked for excessively long hours during the busy seasons which precede the Christmas and Easter holidays. The same state of affairs was found in connection with the children employed in the stores and in the messenger service. The evil was emphasized in an unexpected manner when the principal of one of the largest night schools in the city stated that it was not advisable to visit the night schools in the present month (December) if one wanted to obtain an idea of the educational work carried on, since the schools were almost deserted because so many of the children, including the youngest, were working until late at night. It needs no argument to prove that children under sixteen are not ready for such excessively long working hours, and the beginning of many a case of disease and physical incapacity must date from the exhaustion of the long hours of toil of the holiday season.

It will be noticed that the bill does not provide for any regulation of the sale of newspapers. It is unquestionably true that some restriction of this demoralizing traffic is desirable and would be beneficial, but it is doubtful if Congress would grant such a law. In case the present bill is put into force, the Child Labor Committee will exert its best efforts to remedy such other evils as may call for regulation, and one of the first evils to receive attention will be those connected with the most extensive of the street trades.

Before concluding, your attention is requested to some of the objections which have been urged against the bill. The objection which has been heard most frequently is due to the fact that the bill makes no exception in the case of the children of a widowed mother or invalid father, who because of poverty, may be in need of the earnings of the child who has not yet reached fourteen. It should be stated that there are a number of States which make such an exception, but both the national and the local Child Labor Committees object most earnestly to inserting such a provision in the 
proposed law; first, because it would be an injustice to the child, and, second, because it would open the way to abuses of a serious character.

A careful study of the problem has led the committee to the conclusion that this phase of child labor restriction has been given a prominence altogether unwarranted by the facts. In several cities efforts have been made to ascertain how many families would be forced to apply for charitable aid if the earnings of the children under the statutory age were denied them. In New York, Chicago, and Cleveland, the results of such investigations have uniformly shown that though there are children of widows at work, the number of families which would be forced to ask for aid is very small. At a recent interview, the secretary of the Board of Charities of the District stated that although for many years he had been in daily contact with the poorest of the city's population, he could not at that moment recall from memory a single case where the child's earnings made the difference between self-support and the necessity of asking for outside relief. The agents of the Associated Charities, however, state that such cases are found occasionally, though they are rare. But granting the existence of such cases, can it be claimed that it is the wisest solution of the problem to deny to the poorest of our children all the mental, moral, and physical advantages obtained from attendance at the public schools for the sake of the few dollars of weekly earnings which this sacrifice may bring? Furthermore, such a policy would be a confession that there exists in this community a number of worthy persons who are conspicuously in need of assistance, but that the community prefers that the burden of this relief should be placed on the shoulders of little children rather than have it borne by the community itself. It certainly needs but to state this matter plainly to convince every one of the great injustice which such an exemption would cause. European practice in this connection should be suggestive. Recently an examination was made of the child labor laws of the seven leading European industrial countries. These laws provide for almost every imaginable kind and degree of exemption, but in not one of these countries could a child be deprived of his right to attend the common schools because of the pecuniary misfortunes of his parents. 
Another objection to the proposed child labor law arose from the claim that a compulsory education law would remedy the evils of child labor as they exist in this city. A number of Senators have been especially insistent on this point. As stated before, the Child Labor Committee regards a compulsory education law as absolutely essential to the proper protection of the working children of the District, but that such a law would remove the evils attacked by a child labor law has yet to be proved. The education bill now before Congress provides for the compulsory attendance of children eight to fourteen years of age at a public school or its equivalent. It would therefore prevent the employment of children under fourteen while the schools were in session. To enforce this provision, the truant officers authorized by the act shall visit all places where "children" (as no age limit is specified, this may include all persons under twenty-one) are employed, and as often as twice a year shall demand from the employer a list of such children, with their names and ages. These are the only provisions regulating the employment of children. Experience elsewhere has shown that such lists of working children, with merely a statement of their ages unsupported by documentary evidence, are practically worthless. One of the largest employers of young persons in the city has said that there seem to be no children between the ages of eleven and fourteen if one my judge from the statements of those who apply for work. Until six months ago, in Pennsylvania, the affidavit of the parent as to the age of his child was sufficient to secure an employment certificate, but the wholesale perjury on the part of parents which this provision led to soon nullified the whole child labor law and required a radical change. The simple list of children, therefore, with the ages as reported by the children themselves, will hardly prove an efficient means of detecting the employment of children under the age fixed by the law. It must also be remembered that if the education law alone is to be depended upon for the removal of the evils connected with the employment of children, it means that the day after a child has completed his thirteenth year he may be kept at work for twelve or thirteen hours per day, or he may be employed throughout the night. This would leave absolutely untouched two of the principal evils which the committee is endeavoring to check. The proposed education law 
also takes no account of the educational qualifications of children over fourteen years of age; if an illiterate child of fourteen comes into this city from one of the neighboring states, the compulsory education law would not prevent such a child from securing employment and being deprived of educational opportunities. These statements are not made in any spirit of criticism of the compulsory education bill-that bill is apparently an efficient means of securing educational opportunities to children between the ages of eight and fourteen, but it will not prevent, and indeed was not expected to prevent, the evils connected with the exploitation of child labor now existing in the national capital.

If this discussion of the objections to the proposed child labor law has seemed to deal too much with the obvious and the self-evident, your indulgence is asked on the ground that these have been the very objections which have impeded the progress of the bill and which may possibly hinder its passage. The account of the provisions of the bill is anything but interesting, of course, but perhaps it was worth while in order to make clear what is the aim of the bill and what are the methods by which it is sought to attain this end.

The passing of this bill would be materially assisted if all friends of the movement would write to their members of Congress and urge the early consideration of the measure, both on account of the immediate benefits it would confer on the working children of this city and of the indirect, but very real, benefits which would spring from having a child labor law of a high standard at the nation's capital. 